\title{
FAKTOR-FAKTOR YANG MEMPENGARUHI PROCUREMENT FRAUD DI INSTANSI PEMERINTAHAN (Studi Kasus pada Dinas-Dinas di Kabupaten Buleleng)
}

\author{
Ketut Rian Budi Setiawan', Edy Sujana², Made Arie Wahyuni³
}

Jurusan Ekonomi dan Akuntansi, Fakultas Ekonomi,

Universitas Pendidikan Ganesha, Singaraja, Indonesia

e-mail: rianbudisetia@gmail.com, ediesujana bali@yahoo.com, ariewahyuni@undiksha.ac.id

\begin{abstract}
Abstrak
Penelitian ini bertujuan untuk mengetahui pengaruh kualitas panitia pengadaan barang/jasa, sistem dan prosedur pengadaan barang/jasa, etika pengadaan barang/jasa, lingkungan pengadaan barang/jasa, dan penilaian resiko terhadap procurement fraud pada SKPD di Kabupaten Buleleng. Metode penelitian ini menggunakan pendekatan kuantitatif. Populasi dalam penelitian ini adalah seluruh Kepala Dinas, Sekretaris, Kepala Sub Bagian (Kasubag Umum, Kasubag Perencanaan, Kasubag Keuangan) dari 15 SKPD di Kabupaten Buleleng berjumlah 75 orang. Teknik sampling yang digunakan adalah sampel jenuh yaitu 75 responden. Jenis data yang digunakan adalah data primer yang dikumpulkan dengan metode kuisioner. Untuk menganalisis data menggunakan analisis regresi linier berganda, dan data diolah dengan menggunakan SPSS Versi 19. Hasil penelitian menunjukkan bahwa kualitas panitia, sistem dan prosedur, etika, lingkungan, dan penilaian resiko pengadaan barang/jasa secara parsial berpengaruh negatif terhadap procurement fraud, dan secara simultan berpengaruh signifikan terhadap procurement fraud.
\end{abstract}

Kata Kunci : kualitas panitia, sistem dan prosedur, etika, lingkungan, penilaian resiko, procurement fraud.

Abstract
This study aimed to investigate the effect of the committee quality, the system and procedures, the ethics, the environment and the risk assessment of goods/services procurement fraud at departments of Buleleng Regency. The research method used was quantitative approach. The population of the study were all Heads of Offices, Secretaries, Heads of Subdivisions (Head of General Subdivision, Head of Planning Subdivision, Head of Finance Subdivision) of 15 Departments of Buleleng Regency with the total of 75 people. The sampling technique used was a sample with saturated point of 75 respondents. The type of data used was primary data collected through questionnaire method. To analyze the data, multiple linear regression analysis was used before they were processed by using SPSS Version 19. The results of the study indicate that partially, the quality of the committee, systems and procedures, ethics, environment, and risk assessment of the procurement of goods/services affect the procurement fraud negatively. In addition, simultaneously, they give significant effect on procurement fraud.

Keywords: quality of committee, systems and procedures, ethics, environment, risk assessment, procurement fraud.

\section{Pendahuluan}

Ada berbagai macam fraud telah terjadi di lingkungan Instansi Pemerintah. Salah satu jenis yang paling banyak menimbulkan atau dapat juga disebut salah satu sumber kebocoran keuangan yang paling besar adalah fraud dalam bidang pengadaan barang/jasa. Pengadaan merupakan salah satu sumber korupsi terbesar dalam sektor keuangan publik. Setiap tahun, BPK maupun KPK, melaporkan adanya kasus pengadaan yang mengandung unsur tindak pidana korupsi. Kasus yang terungkap pada RSUD Buleleng yang dihimpun 
Nusa Bali bahwa Badan Pemeriksa Keuangan (BPK) RI menemukan sejumlah pelanggaran dalam proyek di RSUD Buleleng. Temuan BPK terkait proyek RSUD Buleleng tersebut terungkap dalam laporan hasil pemeriksan (LHP) dengan tujuan tertentu atas belanja sarana dan prasarana kesehatan tahun anggaran 2016 dan tahun anggaran 2017. BPK menemukan beberapa kelemahan system pengendalian internal dan ketidakpatutan yang perlu mendapat perhatian Pemkab Buleleng.

Kasus-kasus kecurangan yang terjadi memberikan sumbangan besar terhadap kemerosotan pelayanan jasa bagi rakyat miskin Indonesia. Kegagalan tersebut memberikan indikasi bahwa terdapat kegagalan dalam sistem akuntansi dan adanya konflik kepentingan dalam badan organisasi pemerintah. Oleh sebab itu, diperlukan adanya penelitian mendalam mengenai kejadian tersebut dengan cara mencari faktor-faktor apa saja yang mempengaruhinya, sehingga fraud atau kecurangan yang biasa terjadi pada sektor pengadaan barang/jasa pemerintah dapat ditekan.

Ada beberapa penelitian yang dilakukan terkait dengan fraud, salah satunya penelitian Sartono (2006) mengenai pengaruh kualitas panitia pengadaan barang/jasa, penghasilan panitia pengadaan barang/jasa, sistem dan prosedur pengadaan barang/jasa, etika pengadaan barang/jasa, dan lingkungan pengadaan barang/jasa terhadap penyimpangan dalam pengadaan barang/jasa pada lingkungan instansi pemerintah. Melalui penelitian ini, ditemukan bukti bahwa terdapat perbedaan yang signifikan dalam penilaian terhadap penghasilan panitia pengadaan barang/jasa, sistem dan prosedur pengadaan barang/jasa, etika pengadaan barang/jasa, dan lingkungan pengadaan barang/jasa antara panitia pengadaan dan auditor BPKP, kecuali pada kualitas panitia pengadaan barang/jasa dan secara bersama-sama berpengaruh secara signifikan terhadap penyimpangan dalam pengadaan barang/jasa. Lebih lanjut, hanya variabel lingkungan pengadaan barang/jasa yang berpengaruh secara signifikan terhadap terjadinya penyimpangan dalam pengadaan barang/jasa di lingkungan instansi pemerintah jika dianalisis secara parsial.

Salah satu elemen penting yang mempengaruhi fraud dalam pengadaan barang/jasa adalah kualitas dari panitia penyedia barang/jasa. Jika suatu pengadaan barang/jasa tidak diikuti dengan kualitas penyedia yang baik, maka akan terdapat banyak kesalahpahaman/ misunderstanding di antara panitia dan penyedia barang/jasa yang nantinya akan menimbulkan merugikan kedua belah pihak. Hehamahua (2011) menyebutkan bahwa modus penyimpangan pengadaan barang/jasa pada tingkat panitia pengadaan adalah integritas yang lemah, proses pengadaan yang tidak transparan, panitia pengadaan yang memihak, panitia pengadaan yang tidak independen.

Thai (2001) yang didukung oleh penelitian Jatiningtyas dan Endang (2011) mengungkapkan bahwa profesionalisme atau kualitas panitia pengadaan merupakan faktor yang ikut mempengaruhi keberhasilan suatu sistem pengadaan barang/jasa dalam mencapai tujuan yang telah ditetapkan. Akan tetapi hal ini berbeda dengan penelitian Heljapri (2015) yang menyatakan bahwa kualitas penyedia pengadaan barang/jasa tidak berpengaruh terhadap kenderungan fraud.

Berdasarkan Tool Kit Anti Korupsi yang disusun oleh Indonesia Procurement Watch (2005) dalam Nisa (2017), kegiatan pada segmentasi Pembentukan Panitia Lelang perlu diwaspadai sebagai hal yang menjadi sebab berkembangnya penyakit Korupsi, Kolusi, dan Nepotisme (KKN), yang memuat berbagai muatan "kepentingan", dalam proses pengadaan barang/jasa pemerintah. Panitia Pengadaan yang terbentuk akan menentukan "hitam" atau "putih"nya suatu proses pengadaan peme-rintah mulai dari awal kegiatan pengadaan sampai dengan ditandatanganinya kontrak perjanjian kerja. Segmentasi ini merupakan awal berjangkitnya penyakit-penyakit KKN, diantaranya adalah tersusun atau terbentuknya Panitia Pengadaan yang tidak dilandasi dengan kriteria kemampuan teknis, kredibilitas, serta integritas yang memadai dari anggotanya.

Hasil analisis ini mendukung penelitian yang dilakukan oleh Surya, dkk (2018) bahwa metode pemilihan penyedia barang/jasa memiliki pengaruh signifikan terhadap kualitas pelaksanaan pengadaan barang/jasa di Pemerintah. Selain itu hasil penelitian Jatiningtyas (2011) menyatakan bahwa terdapat perbedaan yang signifikan dalam penilaian terhadap Kualitas Panitia Pengadaan terhadap fraud dalam Pengadaan Barang/ Jasa. 
H1: Kualitas Panitia Pengadaan Barang/Jasa berengaruh secara negatif terhadap Procurement fraud pada SKPD di Kabupaten Buleleng

Sistem pengendalian internal juga mempengaruhi terjadinya fraud. Poernomo (2013) menyatakan bahwa adanya sistem pengendalian yang lemah memberikan peluang para pejabat yang diberi wewenang untuk melakukan penyimpangan. Hal ini juga didukung oleh penelitian Schuchter dan Levi (2015) yang menyatakan bahwa peluang terjajadinya kecurangan dapat terjadi karena kelemahan pengendalian internal organisasi, tidak adanya transparansi, dan juga kurang efektifnya pengendalian intern sehingga menjadikan kecurangan mudah terjadi.

Aspek lain yang ikut menentukan jalannya sistem pengadaan barang/jasa adalah ketentuan dan prosedur pengadaan barang/jasa itu sendiri. Ketentuan dan prosedur pengadaan barang/jasa juga berpengaruh terhadap keberhasilan suatu sistem pengadaan barang/jasa pemerintah dalam mencapai tujuan yang telah ditetapkan (Thai, 2001). Yanavia (2014) menyatakan bahwa sistem dan prosedur pengadaan barang/jasa yang baik dapat mengurangi fraud pengadaan barang/jasa.

Menurut Jourdain dan Balgobin (2003) sebagaimana dikutip Jatiningtyas dan Endang (2011), sistem dan prosedur pengadaan barang/jasa pemerintah yang baik memiliki beberapa karakteristik antara lain: transparency, economy, efficiency and timeliness, fairness and equity. Sistem dan prosedur pengadaan juga harus memiliki mekanisme feedback sehingga memungkinkan upaya perbaikan dan penyempurnaan yang diperlukan. Mekanisme complaint juga perlu diciptakan untuk memperkuat upaya untuk dipatuhinya ketentuan yang digariskan. World Bank (2001) mengungkapkan bahwa salah satu penyebab belum berfungsinya sistem pengadaan barang/jasa di Indonesia secara baik adalah tidak adanya tindak lanjut terhadap berbagai protes dalam proses pengadaan, dan tidak adanya pemantauan yang sistematik terhadap kepatuhan atas peraturan dan prosedur pengadaan.

H2: Sistem dan Prosedur Pengadaan Barang/Jasa berpengaruh negatif terhadap Procurement fraud pada SKPD di Kabupaten Buleleng

Etika pengadaan barang/jasa juga merupakan salah satu aspek penting yang perlu diperhatikan untuk terciptanya pengadaan barang/jasa pemerintah yang sehat. Etika pengadaan berkaitan dengan kelaziman dalam praktek dunia usaha yang dianggap akan menciptakan sistem persaingan usaha yang adil. Etika dalam pengadaan barang/jasa akan mencegah penyalahgunaan wewenang atau kolusi untuk kepentingan pribadi atau golongan yang secara langsung atau tidak langsung dapat merugikan negara.

Tang et al. (2003) dalam Nisa (2017) menjelaskan indikator dari perilaku yang menyimpang atau tidak etis dalam organisasi. Perilaku ini terdiri dari perilaku yang menyalahgunakan kedudukan/posisi (abuse position), perilaku yang menyalahgunakan kekuasaan (abuse power), perilaku yang menyalahgunakan sumber daya organisasi (abuse resources), serta perilaku yang tidak berbuat apa-apa (no action). Jatiningtyas dan Endang (2011) menyatakan bahwa salah satu bentuk perilaku yang etis atau beretika dalam pengadaan barang/ jasa antara lain: para pengguna, penyedia, dan pihak terkait tidak menerima, menawarkan, serta menjanjikan pemberian hadiah atau imbalan berupa apa saja kepada siapa pun yang terkait dengan pengadaan barang/jasa.

Yanavia (2014) menyatakan bahwa etika yang baik perlu diciptakan untuk mencegah terjadinya kolusi dan korupsi dalam kegiatan pengadaan barang/jasa. Selain itu merujuk pada konsep yang dikembangkan oleh Associotion of Certified Fraud Examiners (Kassen dan Higson, 2012) dalam Nisa (2017) menyatakan bahwa salah satu konsep yang relevan untuk menjelaskan isu pencegahan fraud adalah dengan menciptakan keadaan yang memungkinkan pegawai tidak melakukan fraud dengan memiliki konsep pola pikir yang beretika. Berdasarkan pernyataan diatas semakin bagus etika pengadaan barang/jasa maka indikasi fraud dalam pengadaan barang/jasa dapat berkurang.

H3: Etika pengadaan akan berhubungan berpengaruh negatif terhadap Procurement fraud pada SKPD di Kabupaten Buleleng

Sistem dan prosedur pengadaan akan selalu berinteraksi dengan lingkungan dimana sistem tersebut diterapkan. Lingkungan merupakan salah satu faktor yang mempengaruhi kemampuan suatu sistem pengadaan barang/jasa untuk mencapai tujuan yang telah 
ditetapkan (Thai, 2001). Hal ini berbeda dengan penelitian Heljapri (2015) yang didukung oleh penelitian Astuti (2016) menyatakan bahwa lingkungan pengadaan barang/ jasa tidak memiliki pengaruh terhadap fraud pengadaan barang/jasa. Namun, Jatiningtyas dan Endang (2011) yang didukung oleh Thai (2001) menemukan bahwa salah satu faktor yang mempengaruhi keberhasilan adalah lingkungan pengadaan barang/jasa adalah lingkungan pengadaan. Berdasarkan pernyataan diatas semakin bagus lingkungan pengadaan barang/jasa maka indikasi fraud dalam pengadaan barang/jasa dapat ber-kurang.

H4: Lingkungan pengadaan akan berhubungan secara negatif terhadap Procurement fraud pada SKPD di Kabupaten Buleleng

Tuanokota (2007) menyatakan bahwa yang dapat dilakukan untuk mencegah fraud adalah dengan menerapkan pengendalian internal yang mana salah satu komponennya adalah penilaian risiko. Penilaian risiko yang dilakukan diharapkan mempunyai bentengbenteng yang kokoh dan sulit untuk ditembus oleh mereka yang ingin melakukan tindakan fraud pengadaan barang/jasa. Penilaian risiko pengadaan barang/jasa merupakan pekerjaan yang kompleks dengan maksud bahwa pekerjaan yang dilakukan memerlukan teknologi tinggi, mempunyai risiko tinggi, menggunakan peralatan yang didesain khusus.

Hal ini sejalan dengan Fajarina et al., 2011 yang menyatakan bahwa adanya penilaian risiko yang dilakukan oleh pihak pengadaan dengan cara mengidentifikasikan serta melakukan analisis resiko maka akan mengurangi (meminimilasi) terjadinya fraud. Karena itu, penilaian risiko merupakan bagian yang penting dalam hal mencegah fraud agar tercipta kondisi yang baik dalam bekerja (Hermiyetti, 2010). Artinya semakin bagus penilaian risiko pengadaan barang/jasa maka indikasi fraud dalam pengadaan barang/jasa dapat berkurang. H5: Penilaian risiko berhubungan secara negatif terhadap Procurement fraud pada SKPD di Kabupaten Buleleng.

Berdasarkan hasil kajian literatur, peneliti membatasi pembahasan mengenai lima faktor yang mempengaruhi terjadinya fraud dalam pengadaan barang/jasa pemerintah, yaitu kualitas Panitia Pengadaan Barang/Jasa, sistem dan Prosedur Pengadaan Barang/Jasa, etika Pengadaan Barang/Jasa, lingkungan Pengadaan Barang/Jasa dan penilaian resiko terhadap Procurement fraud. Kelima faktor ini merupakan faktor-faktor yang sangat berkaitan erat dengan proses pengadaan barang/jasa sehingga dapat digunakan untuk mengukur adanya fraud dalam kegiatan Pengadaan Barang/Jasa di lingkungan instansi pemerintah. Karena itu peneliti juga menguji secara simultan variabel-variabel tersebut.

H6: Kualitas panitia barang/jasa, sistem dan prosedur pengadaan barang/jasa, etika pengadaan barang/jasa, lingkungan pengadaan barang/jasa, dan penilaian resiko berpengaruh secara silmultan terhadap Procurement fraud pada SKPD di Kabupaten Buleleng

\section{Metode}

Jenis penelitian ini mengunakan pendekatan kuantitatif. Penelitian ini bersifat asosiatif yaitu penelitian yang bersifat menguji hubungan dua variabel atau lebih, dan dalam hal ini hubungan tersebut bersifat kausal dimana variabel bebas mempengaruhi variabel terikat. Adapun variabel bebas dalam penelitian ini meliputi kualitas panitia barang/jasa $\left(X_{1}\right)$, system dan prosedur pengadaan barang/jasa $\left(X_{2}\right)$, etika pengadaan barang/jasa $\left(X_{3}\right)$, lingkungan pengadaan barang/jasa $\left(X_{4}\right)$, dan penilaian resiko $\left(X_{5}\right)$. Sedangkan variabel terikatnya yaitu Procurement fraud $(\mathrm{Y})$.

Populasi dalam penelitian ini adalah adalah seluruh Kepala Dinas, Sekertaris, Kepala Sub Bagian (Kasubag Umum, Kasubag Perencanaan, Kasubag Keuangan) dari 15 SKPD di Pemerintah Daerah Kabupaten Buleleng yang berjumlah 75 orang. Teknik sampling yang digunakan adalah sampel jenuh yaitu 75 responden.

Jenis data yang digunakan dalam penelitian ini adalah data kuantitatif. Sumber data yang digunakan adalah data primer dan sekunder. Pengambilan data tersebut menggunakan kuisioner berupa pernyataan yang diajukan. Kuisioner dibagikan ke pegawai di Dinas seKabupaten Buleleng yang dijadikan sampel dalam penelitian ini. Data yang terkumpul diolah menggunakan alat analisis berupa software SPSS Versi 19, untuk menemukan hasil dari 
masing-masing hipotesis yang telah ditetapkan. Dan data sekunder berupa bentuk-bentuk gambaran umum profil SKPD di Kabupaten Buleleng.

\section{Hasil dan Pembahasan}

Data yang dibutuhkan dalam penelitian ini dikumpulkan melalui observasi dan menyebarkan kuesioner kepada Dinas Se-Kabupaten Buleleng. Berdasarkan survey kuesioner yang disebarkan adalah sebanyak 75 kuesioner yang di sebar di 15 Dinas yang ada di Kabupaten Buleleng pada bulan April 2019. Pengembalian kuesioner dibatasi dengan jangka waktu 2 minggu (14 hari), dan kuesioner yang kembali sebanyak 75 kuesioner. Data tersebut akan dianalisis dan diuji menggunakan bantuan aplikasi Statistical Package for Social Science (SPSS) versi 19 for windows.

Berdasarkan uji validitas diketahui bahwa masing-masing item pertanyaan memiliki $r_{\text {hitung }}$ lebih besar dari $r_{\text {tabel }}\left(r_{\text {hitung }}>r_{\text {tabel }}\right)$. Hal ini berarti masing-masing item pertanyaan dari variabel kualitas panitia barang/jasa, system dan prosedur pengadaan barang/jasa, etika pengadaan barang/jasa, lingkungan pengadaan barang/jasa, penilaian resiko dan Procurement fraud adalah valid.

Uji reliabilitas menunjukan variabel kualitas panitia pengadaan barang/jasa memiliki nilai cronbach alpha 0,878 lebih besar dari 0,60 , system dan prosedur pengadaan barang/jasa memiliki nilai cronbach alpha 0,852 lebih besar dari 0,60, etika pengadaan barang/jasa memiliki nilai cronbach alpha 0,851 lebih besar dari 0,60, lingkungan pengadaan barang/jasa memiliki nilai cronbach alpha 0,880 lebih besar dari 0,60 , penilaian resiko memiliki nilai cronbach alpha 0,885 lebih besar dari 0,60 dan Procurement fraud memiliki nilai cronbach alpha 0,911 lebih besar dari 0,60 maka dapat dikatakan bahwa instrument yang digunakan telah memenuhi syarat reliabilitas. Hasil pengujian normalitas data dengan Uji One Sample Kolmogorof-Smirnov Test menunjukkan hasil bahwa nilai Asymp. Sig (2tailed) sebesar 0,824 lebih besar dari 0,05 atau 5\%. Sehingga dapat dikatakan bahwa data dalam penelitian ini berdistribusi normal.

Hasil pengujian multikolinearitas menunjukan nilai tolerance lebih dari 0,10 yaitu 0,493 untuk variabel Kualitas Panitia $\left(X_{1}\right)$, 0,418 Sistem dan Prosedur $\left(X_{2}\right), 0,486$ Etika Pengadaan $\left(X_{3}\right)$, 0,493 Lingkungan Pengadaan $\left(X_{4}\right)$, dan untuk variabel Penilaian Resiko $\left(X_{5}\right)$ sebesar 0,682 . Dapat dilihat juga dari nilai VIF lebih kecil dari 10 yaitu 2.028 untuk variabel Kualitas Panitia $\left(X_{1}\right), 2,390$ Sistem dan Prosedur $\left(X_{2}\right), 2,060$ Etika Pengadaan $\left(X_{3}\right), 2,029$ Lingkungan Pengadaan $\left(X_{4}\right)$, dan untuk variabel Penilaian Resiko $\left(X_{5}\right)$ sebesar 1,465 . Jadi, dapat disimpulkan bahwa tidak terjadi multikolinearitas antar variabel bebas. Hasil pengujian heteroskedastisitas menunjukkan hasil bahwa tidak terjadi heteroskedastisitas karena, tidak terdapat pola yang jelas dan titik-titik menyebar di atas dan dibawah angka 0 pada sumbu $Y$.

Berdasarkan hasil uji determinasi diketahui bahwa nilai adjusted $\mathrm{R}$ square sebesar 0,698, hal ini menunjukkan bahwa perubahan Procurement Fraud mampu dijelaskan secara bersama-sama oleh perubahan Kualitas Panitia, Sistem dan Prosedur, Etika Pengadaan, Lingkungan Pengadaan dan Penilaian Resiko pengadaan barang/jasa di SKPD Kabupaten Buleleng sebesar 69,8 \%, sedangkan sisanya 30,2\% dijelaskan oleh faktor lain di luar penelitian ini. Sedangakan berdasarkan hasil uji t, diketahui bahwa pertama, kualitas panitia pengadaan barang dan jasa dengan $t_{\text {hitung }}$ sebesar 2,299 lebih besar dari $t_{\text {tabel}}$, sebesar 1,6672 serta dengan nilai signifikansi 0,025 lebih kecil dari 0,05 menunjukan bahwa Kualitas Panitia pengadaan barang/jasa secara negative berpengaruh signifikan terhadap Fraud Pengadaan Barang/Jasa. Kedua, sistem dan prosedur pengadaan barang/jasa dengan $t_{\text {hitung }}$ sebesar 2,009 lebih besar dari $t_{\text {tabel}}$, sebesar 1,6672 serta dengan nilai signifikansi 0,048 lebih kecil dari 0,05 menunjukan bahwa Sistem dan Prosedur pengadaan barang/jasa secara negative berpengaruh signifikan terhadap Fraud Pengadaan Barang/Jasa. Ketiga, Etika pengadaan barang/jasa dengan thitung sebesar 2,109 lebih besar dari $t_{\text {tabel, }}$, sebesar 1,6672 serta dengan nilai signifikansi 0,039 lebih kecil dari 0,05, menunjukan bahwa Etika pengadaan barang/jasa secara negative berpengaruh signifikan terhadap Fraud Pengadaan Barang/Jasa. Keempat, lingkungan pengadaan barang/jasa dengan thitung sebesar 2,076 lebih besar dari $t_{\text {tabel}}$, sebesar 1,6672 serta dengan nilai signifikansi 0,042 lebih kecil dari 0,05, menunjukan bahwa Lingkungan pengadaan barang/jasa secara negative berpengaruh 
signifikan terhadap Fraud Pengadaan Barang/Jasa. Kelima, Penilaian Resiko dengan thitung sebesar 4,843 lebih besar dari $t_{\text {tabel }}$, sebesar 1,6672 serta dengan nilai signifikansi 0,000 lebih kecil dari 0,05, menunjukan bahwa penilaian resiko secara negative berpengaruh signifikan terhadap Fraud Pengadaan Barang/Jasa. Hal ini berarti hipotesis pertama, kedua, ketiga,keempat dan kelima diterima. Berdasarkan hasil analisis regresi berganda dihasilkan model regresi:

$Y=69,597-0,380 X_{1}-0,277 X_{2}-0,294 X_{3}-0,355 X_{4}-0,518 X_{5}+\varepsilon$

Berikut ini merupakan hasil uji t

Tabel 1.1 Hasil Uji t

\begin{tabular}{|c|c|c|c|c|c|}
\hline \multirow[b]{2}{*}{ Model } & \multicolumn{2}{|c|}{$\begin{array}{l}\text { Unstandardized } \\
\text { Coefficients }\end{array}$} & \multirow{2}{*}{$\begin{array}{c}\text { Standardized } \\
\text { Coefficients } \\
\text { Beta }\end{array}$} & \multirow[b]{2}{*}{$\mathrm{T}$} & \multirow[b]{2}{*}{ Sig. } \\
\hline & B & $\begin{array}{l}\text { Std. } \\
\text { Error }\end{array}$ & & & \\
\hline (Constant) & 69,597 & 3,564 & & 19.528 & 0,000 \\
\hline Kualitas_Panitia & $-0,380$ & 0,165 & $-0,209$ & $-2,299$ & 0,025 \\
\hline Sistem_dan_Prosedur & $-0,277$ & 0,138 & $-0,198$ & $-2,009$ & 0,048 \\
\hline Etika_Pengādaan & $-0,294$ & 0,140 & $-0,193$ & $-2,109$ & 0,039 \\
\hline Lingküungan_Pengadaan & $-0,355$ & 0,171 & $-0,189$ & $-2,076$ & 0,042 \\
\hline Penilaian Resiko & $-0,518$ & 0,107 & $-0,374$ & $-4,843$ & 0,000 \\
\hline
\end{tabular}

Berdasarkan hasil uji $\mathrm{F}$ menunjukan nilai $\mathrm{F}_{\text {hitung }}$ sebesar 35,233 lebih besar dari $\mathrm{F}_{\text {tabel }}$ sebesar 2,35 dengan angka signifikansi $=0,000<\alpha=0,05$. Hal ini berarti bahwa secara simultan terdapat pengaruh antara kualitas panitia, system dan prosedur, etika, lingkungan dan penilaian risiko berpengaruh signifikan secara simultan terhadap Procurement Fraud pada SKPD di Kabupaten Buleleng. Berikut hasil uji F:

Tabel 1.2 Hasil Uji F

\begin{tabular}{|c|c|c|c|c|c|c|}
\hline \multirow[b]{2}{*}{ Model } & & \multicolumn{3}{|c|}{$\mathrm{ANOVA}^{\mathrm{b}}$} & \multirow[b]{2}{*}{$\mathrm{F}$} & \multirow[b]{2}{*}{ Sig. } \\
\hline & & $\begin{array}{l}\text { Sum of } \\
\text { Squares }\end{array}$ & $d f$ & Mean Square & & \\
\hline 1 & Regression & 1427,878 & 5 & 285,576 & 35,233 & $0,000^{a}$ \\
\hline & Residual & 559,269 & 69 & 8,105 & & \\
\hline & Total & 1987,147 & 74 & & & \\
\hline
\end{tabular}

a. Predictors: (Constant), Penilaian_Resiko, Kualitas_Panitia, Lingkungan_Pengadaan,

Etika_Pengadaan, Sistem_dan_Prosedur

b. Dependent Variable: Procurement_Fraud

Hipotesis pertama yang menyatakan bahwa kualitas panitia pengadaan barang/jasa berpengaruh negatif terhadap procuremenr fraud diterima. Pada penelitian ini kualitas panitia pengadaan barang/jasa diukur dengan indikator formatif yang dijabarkan ke dalam 6 item pertanyaan. Diketahui bahwa indikator kualitas panitia (KP) 5 yang dinyatakan dengan "Panitia lelang telah memiliki sertifikat keahlian pengadaan barang/jasa atau pernah mengikuti pelatihan pengadaan barang/jasa" memiliki mean terendah yaitu 3,87 . Hal tersebut menunjukkan panitia lelang cenderung belum semua memiliki sertifikat keahlian pengadaan barang/jasa atau cenderung jarang mengikuti pelatihan pengadaan barang/jasa. Diketahui pula bahwa KP 6 yang dinyatakan dengan "Dalam penyusunan panitia berdasarkan pada kriteria kemampuan teknis, mempunyai kredibilitas dan integritas sehingga tidak memihak kepada salah satu atau sekelompok peserta dalam proses pengadaan barang/jasa" memiliki mean tertinggi yaitu 4,00. Hal tersebut menunjukkan bahwa panitia cenderung memiliki kredibilitas dan integritas sehingga tidak memihak kepada salah satu atau sekelompok peserta dalam proses pengadaan barang/jasa.

Panitia pengadaan merupakan salah satu subyek (pelaku) pengadaan barang/jasa pemerintah dan aktivitas serta keputusan yang dilakukannya akan sangat menentukan jalannya proses pengadaan. Segala aktivitas dan keputusan yang diambil oleh panitia pengadaan merupakan hal yang sangat krusial karena berhadapan langsung dengan 
muatan kepentingan dari berbagai subyek pengadaan barang/jasa lainnya. Untuk itu kemampuan dan profesionalisme personil panitia pengadaan merupakan hal yang perlu diperhatikan. Apabila dalam kepanitiaan terdapat salah seorang oknum yang biasa melakukan KKN, maka akan mendorong tindak kecurangan/fraud pada aktivitas pengadaan barang/jasa.

Untuk meningkatkan kualitas panitia pengadaan, seorang panitia sangat bergantung pada tingkat profesionalisme dan kemampuannya. Profesionalisme dalam penelitian ini diproksikan dalam integritas panitia, kompetensi, obyektifitas dan independensi. Ketika seorang panitia bertindak professional, maka konflik kepentingan diantara principal dan agen dapat terhindari karena panitia bekerja berdasarkan standar operasional tanpa ada keinginan untuk berbuat kecurangan. Hasil penelitian ini sejalan dengan penelitian yang dilakukan oleh Surya, dkk (2018) bahwa metode pemilihan penyedia barang/jasa memiliki pengaruh signifikan terhadap kualitas pelaksanaan pengadaan barang/jasa di Pemerintah. Selain itu hasil penelitian Jatiningtyas (2011) menyatakan bahwa terdapat perbedaan yang signifikan dalam penilaian terhadap Kualitas Panitia Pengadaan terhadap fraud dalam Pengadaan Barang/Jasa.

Hipotesis kedua yang menyatakan bahwa sistem dan prosedur pengadaan barang/ jasa mempunyai pengaruh negative terhadap procuremenr fraud diterima. Pada penelitian ini sistem dan prosedur pengadaan barang/jasa diukur dengan indikator formatif yang dijabarkan ke dalam 7 item pertanyaan. Diketahui pula bahwa indikator Sistem dan Prosedur (SP) 6 yang dinyatakan dengan "Dokumen lelang diperuntukkan bagi kelompok penyedia barang /jasa tertentu saja" memiliki mean terendah yaitu 3,59. Hal tersebut menunjukkan masih kurang efisien nya pelaksanaan dokumen lelang yang ada, seharusnya dokumen ditunjukkan kepada pihak yang berkaitan saja agar pengambilan keputusan bisa cepat dan efisien. Diketahui pula bahwa (SP) 1 yang dinyatakan dengan "Dalam pengumuman pengadaan barang/jasa dilakukan melalui media cetak /media elektronik/ internet" memiliki mean tertinggi yaitu 3,93. Hal tersebut menunjukkan bahwa sistem pengadaan barang/jasa sudah lebih transaparan dengan dilakukannya pengumuman pengadaan barang/jasa melalui berbagai media.

Ketentuan dan prosedur pengadaan barang/jasa juga berpengaruh terhadap keberhasilan suatu sistem pengadaan barang/jasa pemerintah dalam mencapai tujuan yang telah ditetapkan (Thai, 2001). Sistem dan prosedur pengadaan barang/jasa pemerintah yang baik memiliki beberapa karakteristik antara lain: transparancy, economy, efficiency and timeliness, fairness and equity. Sistem dan prosedur pengadaan juga harus memiliki mekanisme feedback sehingga memungkinkan upaya perbaikan dan penyempurnaan yang diperlukan. Mekanisme complaint juga perlu diciptakan untuk memperkuat upaya untuk dipatuhinya ketentuan yang digariskan.

Sistem dan prosedur pengadaan barang/jasa yang baik dan efektif dapat mengurangi atau bahkan menutup peluang untuk melakukan kecenderungan kecurangan (fraud). Kecenderungan kecurangan dapat terjadi apabila ada peluang.peluang yang besar membuat kecenderungan kecurangan lebih sering terjadi.Peluang tersebut dapat dikurangi dengan sistem dan prosedur pengadaan barang/jasa yang efektif. Hasil penelitian ini sejalan dengan penelitian yang dilakukan oleh Mirza (2013) bahwa semakin tinggi (efektif) kepatuhan pegawai terhadap sistem pengendalian intern yang diterapkan suatu instansi maka semakin rendah tingkat fraud di sector pemerintahan yang terjadi. Selain itu hasil penelitian Jatiningtyas, Nurani (2011) menyatakan bahwa sistem prosedur pengadaan barang/jasa berpengaruh negatif terhadap fraud pengadaan barang/ jasa.

Hipotesis ketiga yang menyatakan bahwa etika pengadaan barang/jasa mempunyai pengaruh negative terhadap procuremenr fraud diterima. Pada penelitian ini Etika pengadaan barang/jasa diukur dengan indikator formatif yang dijabarkan ke dalam 4 item pertanyaan. Diketahui bahwa indikator etika (EP) 2 yang dinyatakan dengan "Dalam proses pengadaan barang/jasa adalah wajar bila mengijinkan peserta pengadaan bertindak sebagai calo" memiliki mean terendah yaitu 2,64. Hal tersebut menunjukkan kecenderungan peserta pengandaan barang/jasa tidak ikut bertindak sebagai calo, hal ini sudah sejalan dengan etika pengandaan barang/jasa. Diketahui pula bahwa (EP) 4 yang dinyatakan dengan "Anda 
sebagai panitia diminta untuk menandatangani legalitas administrasi pengadaan barang/jasa" memiliki mean tertinggi yaitu 3,36. Hal tersebut menunjukkan bahwa hanya panitia yang berwenang yang berhak untuk menandatangani legalitas administrasi pengadaan barang/jasa.

Etika dalam pengadaan barang/jasa akan mencegah penyalahgunaan wewenang atau kolusi untuk kepentingan pribadi atau golongan yang secara langsung atau tidak langsung dapat merugikan negara. Etika pengadaan barang/jasa yang baik perlu diciptakan untuk mencegah terjadinya kolusi atau korupsi dalam pengadaan barang/jasa pemerintah. Salah satu bentuk etika pengadaan barang-jasa antara lain : para pengguna, penyedia, dan pihak terkait tidak menerima, menawarkan, serta menjanjikan pemberian hadiah atau imbalan berupa apa saja kepada siapa pun yang terkait dengan pengadaan barang/jasa.

Hasil penelitian ini sejalan dengan penelitian yang dilakukan oleh Jatiningtyas, Nurani (2011) menyatakan bahwa etika pengadaan barang/jasa berpengaruh negatif terhadap fraud pengadaan barang/ jasa. Namun hasil penelitian ini tidak sejalan dengan penelitian Mirza (2013) yang menyatakan bahwa etika pengadaan barang/jasa tidak berpengaruh terhadap fraud pengadaan barang/ jasa. Hal ini bisa jadi karena perbuatan tidak etis itu sulit untuk dimengerti dan diprediksi. Kemungkinan lain adalah kuatnya pengaruh Kualitas panitia serta sistem dan prosedur maka fraud dapat dicegah.

Hipotesis keempat yang menyatakan bahwa lingkungan pengadaan barang/jasa mempunyai pengaruh negative terhadap procuremenr fraud diterima. Pada penelitian ini Lingkungan pengadaan barang/jasa diukur dengan indikator formatif yang dijabarkan ke dalam 6 item pertanyaan. Diketahui bahwa indikator lingkungan (LP) 2 yang dinyatakan dengan "Penentuan jenis barang/jasa sesuai dengan yang dibutuhkan oleh pengguna" memiliki mean terendah yaitu 3,89. Hal tersebut menunjukkan bahwa penentuan jenis barang/jasa masih cenderung belum sesuai dengan kebutuhan pengguna. Diketahui pula bahwa (LP) 5 yang dinyatakan dengan "Semua kegiatan dalam pengadaan barang/jasa mengacu pada peraturan peraturan perundang-undangan" memiliki mean tertinggi yaitu 4,11. Hal tersebut menunjukkan bahwa tugas dan tanggung jawabnya dijalankan sesuai ketentuan yang berlaku tanpa ada intervensi dari pihak lain

Lingkungan merupakan salah satu faktor yang mempengaruhi kemampuan suatu sistem pengadaan barang/jasa untuk mencapai tujuan yang telah ditetapkan (Thai, 2001). Aspek lingkungan meliputi lingkungan internal maupun eksternal. Lingkungan internal dalam pengadaan barang/jasa pemerintah adalah kondisi lingkungan kerja. Kondisi lingkungan kerja yang lebih baik bagi aparatur pemerintah akan memberikan insentif kepada mereka untuk bekerja dengan jujur yang pada akhirnya akan menurunkan tingkat korupsi (Azfar, Lee, Swamy, 2000 dalam Sartono, 2006). Sedangkan lingkungan eksternal meliputi semua hal yang berkaitan kegiatan pengadaan barang/jasa pemerintah.

Kemampuan pimpinan untuk menciptakan dan memelihara lingkungan kerja yang kondusif akan menjadi motivasi kuat bagi para pegawai untuk memberikan yang terbaik dalam pelaksanaan pekerjaannya. Sebaliknya, pimpinan yang tidak/ kurang kompeten dalam menciptakan lingkungan yang positif akan berpotensi mempengaruhi pegawai untuk melakukan hal-hal negative yang dapat merugikan instansinya.Hasil penelitian ini sejalan dengan penelitian yang dilakukan oleh Jatiningtyas, Nurani (2011) menyatakan bahwa lingkungan pengadaan barang/jasa berpengaruh terhadap fraud pengadaan barang/ jasa.

Hipotesis kelima yang menyatakan bahwa penilaian resiko mempunyai pengaruh negative terhadap procuremenr fraud diterima. Pada penelitian ini penilaian resiko pengadaan barang/jasa diukur dengan indikator formatif yang dijabarkan ke dalam 5 item pertanyaan. Diketahui bahwa indikator penilaian resiko (PR) 3 yang dinyatakan dengan "Kurangnya integritas dan ketidakadilan penyedia barang/jasa" memiliki mean terendah yaitu 2,96. Hal tersebut menunjukkan bahwa integritas dan keadilan penyedia barang/jas cenderung baik. Diketahui pula bahwa (PR) 5 yang dinyatakan dengan "Dilakukan analisis risiko dari setiap tahapan proses pengadaan pengadaan barang/jasa" memiliki mean tertinggi yaitu 3,57. Hal tersebut menunjukkan bahwa telah dilakukan analisis risiko dari setiap tahapan proses pengadaan pengadaan barang/jasa. 
Komponen penilaian risiko merupakan salah satu langkah untuk menghindari fraud. Penilaian risiko yang dilakukan diharapkan mempunyai benteng-benteng yang kokoh dan sulit untuk ditembus oleh mereka yang ingin melakukan tindakan fraud pengadaan barang/jasa. Penilaian risiko pengadaan barang/jasa merupakan pekerjaan yang kompleks dengan maksud bahwa pekerjaan yang dilakukan memerlukan teknologi tinggi, mempunyai risiko tinggi, menggunakan peralatan yang didesain khusus. Hal ini didasari dari penelitian (Fajarina et al., 2011) yang mengatakan bahwa adanya penilaian risiko yang dilakukan oleh pihak pengadaan dengan cara mengidentifikasikan serta melakukan analisis resiko maka akan mengurangi (meminimilasi) terjadinya fraud. Hasil penelitian ini sejalan dengan penelitian yang dilakukan oleh Nisa, Nashirotun (2017) menyatakan bahwa penilaian risiko berpengaruh terhadap fraud pengadaan barang/ jasa. Apabila penilaian risiko tidak diterapkan maka akan meningkatkan tindakan fraud.

Hipotesis keenam yang menyatakan bahwa kualitas panitia, sistem dan prosedur, etika, lingkungan pengadaan barang/jasa dan penilaian resiko mempunyai pengaruh terhadap procuremenr fraud diterima. Pada penelitian ini Fraud pengadaan barang/jasa diukur dengan indikator formatif yang dijabarkan ke dalam 9 item pertanyaan. Diketahui bahwa indikator Procurement Fraud (PF) 5 yang dinyatakan dengan "Penggadaan barang/jasa tidak sesuai dengan permintaan pengguna barang". memiliki mean terendah yaitu 3,41 . Hal tersebut menunjukkan bahwa pengadaan barang dan jasa cenderung masih belum sesuai dengan permintaan pengguna barang/jasa. Diketahui pula bahwa (PF) 1 yang dinyatakan dengan "Pertimbangan waktu pengumuman pengadaan berdasarkan kompleksitas barang /jasa" memiliki mean tertinggi yaitu 3,84. Hal tersebut menunjukkan bahwa dalam pengumuman pengadaan sudah berdasarkan atas tingkat kompleksitas pengadaan pengadaan barang/jasa.

Hasil penelitian ini mengindikasikan bahwa semakin baik tingkat kualitas panitia pengadaan, system dan prosedur pengadaan barang, etika pengadaan barang/jasa, lingkungan pengadaan barang/jasa dan penilaian risiko, maka fraud pengadaan barang/jasa berkurang. Berdasarkan hasil penelitian ini maka Pemimpin SKPD harus mampu menjaga kualitas panitia pengadaan barang/jasa, ketaatan pada sistem dan prosedur pengadaan, etika pengadaan barang/jasa, lingkungan pengadaan barang/jasa serta dilakukannya penilaian risiko dalam melakukan pengadaan barang/jasa. Hal ini bertujuan guna meminimalisir fraud pada pengadaan barang/jasa.

\section{Simpulan dan Saran}

Berdasarkan hasil analisis data dan pembahasan sebelumnya disimpulkan bahwa ada pengaruh negatif secara parsial dari variabel kualitas panitia, sistem dan prosedur pengadaan barang/jasa, etika pengadaan barang/jasa, lingkungan, dan penilaian resio terhadap Procurement Fraud. Hal ini berarti apabila kualitas panitia, sistem dan prosedur pengadaan barang/jasa, etika pengadaan barang/jasa, lingkungan, dan penilaian resio semakin tinggi/ baik maka mengakibatkan mengurangi (meminimalisasi) terjadinya fraud. Selain itu berdasarkan hasil penelitian secara simultan, ditemukan bahwa kualitas panitia pengadaan, sistem dan prosedur pengadaan barang, etika pengadaan barang/jasa, lingkungan pengadaan barang/jasa dan penilaian risiko berpengaruh signifikan terhadap fraud pengadaan barang/jasa.

Bedasarkan hasil penelitian, peneliti menyarankan bahwa SKPD di Kabupaten Buleleng perlu untuk, pertama, meningkatkan kualitas SDM panitia pengadaan barang/jasa harus lebih maksimal misalnya dengan mengikuti pelatihan-pelatihan terkait dengan pengadaan barang/jasa. Kedua, sistem dan prosedur pengadaan barang agar diperhatikan dan dilaksanakan dengan baik agar pelaksanaan pengadaan barang/jasa berjalan dengan efisien dan efektif dan ketiga, penentuan jenis barang/jasa harus sesuai dengan yang dibutuhkan oleh pengguna. Selain itu, bagi peneliti selanjutnya agar dapat memperluas ruang lingkup penelitian tidak hanya di lingkup pemerintahan saja melainkan bisa di lingkup perusahaan swasta, dan dapat mengembangkan penelitian ini dengan menambah variabel lain atau dapat meneliti faktor-faktor lain yang dapat mempengaruhi fraud pengadaan barang/jasa di suatu perusahaan. 


\section{Daftar Pustaka}

Astuti, H. 2016. Analisis Faktor-Faktor Yang Mempengaruhi Fraud Pengadaan Barang/ Jasa Di Lingkungan Instansi Pemerintah Provinsi Kepulauan Riau. Skripsi. Universitas Maritim Raja Ali Haji.

Badan Pengawasan Keuangan (BPK). 2017. Ikhtisar Hasil Pemeriksaan Semester II Tahun 2017. Jakarta.

Badan Pengawasan Keuangan dan Pembangunan (BPKP). 2017. Laporan Hasil Pengawasan di Wilayah Provinsi Bali 2017. Denpasar.

Fajarina,Darwanis., W dan Bakar U., A. 2012. Pengaruh Lingkungan Pengendalian, Penilaian Resiko, Kegiatan Pengendalian, Informasi dan Komunikasi, Serta Pemantauan Terhadap Pencegahan Fraud Pengadaan Barang/Jasa Pada SKPD Di Pemerintah Aceh. Jurnal Akuntansi Pascasarjana Universitas Syiah Kuala.

Hehamahua. 2011. Pengadaan Barang dan Jasa, Korupsi dan Reformasi Birokrasi. http://www.lkpp.go.ig, diakses pada tanggal 12 Juli 2018.

Heljapri. 2015. Perbedaan Persepsi Antara Pihak Internal Instansi Pemerintah Dengan Auditor BPKP Tentang Aspek Penyebab Fraud Pengadaan Barang/Jasa Pada Lingkungan Pemerintah Propinsi Sumatera Barat (Studi Empiris pada SKPD Kabupaten/Kota dan auditor BPKP Sumatra Barat). Skripsi. Universitas Negeri Padang.

Jatiningtyas, N. 2011. Analisis Faktor-Faktor Yang Mempengaruhi Fraud Pengadaan Barang/Jasa Pada Lingkungan Instansi Pemerintah Di Wilayah Semarang. Skripsi. Universitas Diponegoro.

Mirza, R., Z. 2013. Faktor-faktor yang Mempengaruhi terjadinya Fraud di Sektor Pemerintahan (studi Kasus pada Dinas Se-Kota Surakarta). Skripsi. Universitas Negeri Semarang.

Nisa, N. 2016. Peranan Panitia Pengadaan Barang/Jasa Dalam Mengurangi Fraud Di Perguruan Tinggi (Studi Kualitatif). Issn 2460-0784. Surakarta.

Poernomo, H. 2013. BPK RI Serahkan IHPS II Tahun 2012 ke DPR RI. Diakses tanggal 8 Juli 2018. http://www.bpk.go.id/web/?p=14466.

Sartono. 2006. Analisis Faktor-Faktor yang Mempengaruhi Terjadinya Penyim-pangan dalam Pengadaan Barang/Jasa di Lingkungan Instansi Pemerintah. Tesis, Universitas Indonesia.

Schuchter, A. dan Levi., M. 2015. Beyond the Fraud Triangle: Swiss and Austrian Elite Fraudsters. Accounting Forum, 39 (3), 176-187.

Sugiyono. 2013. Metode Penelitian Kuantitatif dan Kualitatif dan R\&D, Penerbit Alfabeta Bandung.

Thai, K. V. 2001. Public Procurement Re-examined. Journal Of Public Procurement, Volume 1 , Issue 1, 9-50

Tuanakota. 2012. Akuntansi Forensik \& Audit Investigasi. Penerbit Salemba Empat.

Yanavia. 2014. Analisis Faktor-Faktor Yang Mendorong Terjadinya Fraud Pengadaan Barang/Jasa Pada Instansi Pemerintah Di Propinsi Sumatera Barat. Skripsi. Universitas Negeri Padang. 